\title{
Araştırma Makalesi/Research Article (Original Paper) \\ Van İlinde Domatesin Yaygın Olarak Yetiştirildiği Alanların Toprak Özellikleri İle Domates Bitkisinin Beslenme Durumunun Belirlenmesi
}

\author{
Sezgin Bayram, Füs un Gülser* \\ Van Yüzüncü Yıl Üniversitesi, Ziraat Fakültesi, Toprak Bilimi ve Bitki Besleme Bölümü, Van, Türkiye \\ *e-posta: fgulser@yyu.edu.tr
}

Öz: $\mathrm{Bu}$ çalışmada Van ilinde domatesin yaygın olarak yetiştirildiği Erciş, Gevaş ve Edremit ilçelerinde domates bitkisinin beslenme durumunun belirlenmesi amaçlanmıştır. $\mathrm{Bu}$ amaçla alınan bitki ve toprak örneklerinin analizleri sonucunda topraklarda organik maddenin $(\leq \% 2.5)$, azot $(\leq \% 0.90)$ ve yarayışlı fosfor içeriklerinin yetersiz $(\leq 8.0 \mathrm{mg} / \mathrm{kg})$ olduğu belirlenmiştir. Bitkilerde azot $(\leq \% 3.19)$ noksanlığ 1 tespit edilmiştir. Bitkilerin ortalama azot içeriği \% 2.3 olarak yetersiz düzeyde belirlenmiştir. Ayrıca aynı lokasyonda bahçeler arasında toprak özelikleri ve bitkilerin besin elementi içerikleri bakımından istatistiksel anlamda önemli farklılıklar bulunmuştur.

Anahtar kelimeler: Besin Elementi, Domates, Toprak, Toprak özellikleri

\section{The Determination of Nutrition Status of Tomatoes Grown in Van Province and Soil Properties of Common Fields}

\begin{abstract}
This study aimed to determine nutrition status of tomatoes in Erciş, Gevaş and Edremit towns province Van where tomato widely cultivated. According to results of soil and plant samples an analyses, organic matter $(\leq 2.5 \%)$, nitrogen $(\leq 0.90 \%)$ and phosphorus $\left(\leq 8.0 \mathrm{mg} \mathrm{kg}^{-1}\right)$ content were determined at unsufficient levels in soils. Nitrogen contents of plants were determined as $2.3 \%$ at in unsufficient levels. In the same location, significant differences among gardens were found about soil properties and nutrient content of plant.
\end{abstract}

Keywords: Nutrient, Tomato, Soil, Soil properties

\section{Giriş}

Domates (Solanum lycopersicum); dünyada en çok üretilen, tüketilen ve ekonomik önemi olan ürünlerin arasında yer alması; insan beslenmesinde vazgeçilmez bir ürün olması ve gida sanayisinde salça, konserve, turşu, ketçap gibi çok çeşitli kullanım alanlarına sahip olması ile önemli gıda ürünlerinin başında gelmektedir. Dünyada birçok ülkede yetiştirilmekte olup yaklaşık 48.5 milyon ton üretim ile Çin 2011 yılında birinci sırada yer alır. Bunu Hindistan 16.8 milyon ton, Amerika 12.5 milyon ton ve Türkiye 11 milyon ile takip etmektedir (Keskin 2012).

Domatesin ana vatanı Güney Amerika'dır. Solaneceae familyasına ait kültür bir bitkisi olan domates, tropik bölgelerde çok yıllık ve diğer bölgelerde ise tek yıllıktır. Amerika'nın keşfinden sonra Avrupa'ya gönderilen domates zehirli sanıldığı için yasaklanmıştır. 1500'lü yıllarda yiyecek olarak tüketilen domates Türkiye'de ise 18. yüzyıldan itibaren yetiştirilmeye başlanmıştır.

Ilık ve sıcak iklimler domates yetiştiriciliği için uygundur. $\mathrm{Bu}$ bitki soğuğa karşı dayanıklı değildir. Vejetasyon dönemde -2 ve $-3{ }^{\circ} \mathrm{C}$ sıcaklıklar bitkinin ölümüne neden olmaktadır. Vejetasyon dönemindeki uygun iklim koşullarının 4 aydan kısa süreli olması verimi olumsuz etkilemektedir. Domates bitkisi optimum gelişme için en az $16-19{ }^{\circ} \mathrm{C}$ sıcaklığa ihtiyaç duymaktadır. Meyve bağlama $32{ }^{\circ} \mathrm{C}$ 'nin üzerindeki ve $15^{\circ} \mathrm{C}$ 'nin altındaki sıcaklıklarda azalmaktadır (Anonim 2008). 
Domatesin su tutma kapasitesi yüksek, organik madde ve besin maddeleri bakımında zengin, tınlı bünyeli pH 5'ten yüksek topraklarda optimum gelişme gösterdiği bildirilmiştir (Anonim 2008).

Domates su isteği fazla olan bir bitkidir. Çimlenme, çıkış, çiçeklenme ve meyve olma dönemleri bitkinin nem eksikliğine en duyarlı olduğu dönemlerdir (Anonim 2008). Uygun iklim koşulları nedeniyle Türkiye domates üretiminde önemli ülkelerden biridir. Yetiştiriciliği yapılan bölgelerde, ülke ekonomisinde önemli bir yeri olan domates çiftçimizin önemli gelir kaynaklarından birini oluşturmaktadır. Özellikle Marmara, Akdeniz ve Ege'de önemli ölçüde domates yetiştirilmektedir. Diğer bölgelerde de domates yetiştiriciliği yapılmakta ise de bu üç bölge domates ihtiyacının büyük bir bölümünü karşılamaktadır (Anonim 2016).

Sofralık domates üretimi Akdeniz bölgesinde, sanayi tipi domates üretimi ise daha çok Marmara ve Ege Bölgelerinde (Bursa, Manisa ve İzmir) yoğunlaşmıştır. Domates vücudumuz için gerekli C, A, E, K, B1, B2, B3, B5, B6 vitaminlerinin yanı sıra potasyum, magnezyum, demir ve fosfor minerallerini içerir. Ortalama büyüklükteki bir domates (123 gram) 22 kaloridir ve 1 gram protein ve 4.8 gram karbonhidrat içerir. C vitamini bakımında çok zengin olan 1 adet domates günlük C vitamini ihtiyacımızın \% 25'ini, A vitamini gereksiniminin \% 20'sini günlük lif ihtiyacının \% 5'ini karşılamaktadır (Anonim 2011).

Ülkemizde üretimi yapılan domatesin yaklaşık \% 20-30’u gıda sanayinde işlenmekte, kalan miktar ise sofralık olarak taze tüketimde kullanılmaktadır. İşlenen toplam miktarın \% 80’i salça, \% 15'i konserve domates üretimi için kalan kısım ise ketçap, domates suyu vb. domates ürünlerinin imalatı için kullanılmaktadır (Sarısaçlı 2009). Artan domates tüketimine baktığımızda, domatesin insan sağlığ1 açısından tüketiminin yanında üretimin ekonomik katkısının da ne kadar önemli olduğu anlaşılmaktadır.

Van ilinde de en çok yetiştirilen sebzelerin başında domates gelmektedir. Van ilinde Erciş, Gevaş ve Edremit'te yaygın olmak üzere toplam 5663.0 dekar alanda domates üretimi yapılmaktadır. Verim ise 15 017.0 ton olarak belirtilmiştir (Anonim 2016).

Ülkemizde ve Van'da yaygın olarak üretilmekte olan domates bitkisinde verim ve kaliteyi artırmak amacı ile yapılabilecek araştırmalar, ekonomik değeri olan domates yetiştiriciliğine katkı sağlaması bakımında önem taşımaktadır. Domatesin kumludan killiye kadar derin geçirgen ve su tutma kabiliyeti iyi humus ve besin maddelerince zengin tınlı topraklarda ürün verdiği belirtilmiştir (Anonim 2011). Bu bakımdan araştırma alanı topraklarının ve domates bitkisinin besin elementi içeriği bakımından incelenmesinin ve bunun sonucunda ortaya çlkabilecek besin elementi eksikliklerinin belirlenmesinin ilerde gerçekleştirilecek gübreleme programları için faydalı ve dolayısı ile verim artışında etkili olabileceği düşünülmüştür.

Van ilinde domates bitkisinin beslenme durumu ve birebir yetiştiği lokasyonlardaki toprak özellikleri ile ilgili bir çalışma yapılmamıştır. Bu çalışmada domates bitkisinin yaygın olarak yetiştiği alanlarda toprak özellikleri ile bitkinin besin elementi içeriklerinin belirlenmesi amaçlanmıştır.

\section{Materyal Yöntem}

\section{Araştırma yerinin tanıtımı}

$\mathrm{Bu}$ araştırma Van ilinde domatesin yoğun olarak yetiştirildiği Erciş Gevaş ve Edremit ilçelerinde şansa bağlı olarak seçilen her bir örnekleme noktasında toprak ve yaprak örnekleri alınarak yürütülmüştür. Bitki ve toprak örneklerinin alındığı lokasyonlar Şekil 1'de gösterilmiştir.

Erciş’te iklim 1lıman geçmektedir. Kış ayları en çok yağışın düştüğü aylardır. Yağış miktarı yıllık ortalama 466 mm'dir. Ağustos, $7 \mathrm{~mm}$ yağışla yılın en kurak ayıdır, en fazla yağış Nisan ayında görülmektedir. Erciş ilçesinin yıllık ortalama sıcaklığ $18.5^{\circ} \mathrm{C}$ 'dır. Yıllık ortalama sıcaklık $10{ }^{\circ} \mathrm{C}$ 'dir. 21.8 ${ }^{\circ} \mathrm{C}$ sicaklıkla yılın en sıcak ayı Temmuz'dur. Yılın en düşük ortalaması Ocak ayında ortalama sicaklık olarak -4.9 ${ }^{\circ} \mathrm{C}$ 'dir (Anonim 2017). Erciş ilçesi topraklarının Kireçsiz Kahverengi büyük toprak grubunda yer aldığı bildirilmiştir. Bu toprak grubunda kumlu tınlı, kumlu killi, tınlı bünye ve kalsiyum yıkanması ile nötr toprak reaksiyonu ön plana çıkan toprak özelikleridir (Anonim 1991). 
Gevaş ilçesinin iklimi ılıman geçmektedir. Yağış miktarı yıllık ortalama 500 mm’dir. Temmuz, 6 mm yağışla yılın en kurak ayıdır. Ortalama $79 \mathrm{~mm}$ yağış miktarıyla en fazla yağış Nisan ayında görülmektedir. Gevaş ilçesinin yıllık ortalama sıcaklığ $10{ }^{\circ} \mathrm{C}$ 'dır. Temmuz, $21.6{ }^{\circ} \mathrm{C}$ sıcaklıkla yılın en sıcak ayıdır. Yılın en düşük ortalaması Ocak ayında ortalama sıcaklık olarak -2 C'dir (Anonim 2017). Gevaş ilçesi toprakları kestane rengi büyük toprak grubuna dahil edilmektedir. Bu toprak grubunda B horizonunda Kil birikmesi ve B horizonun altında kireç birikme tabakası bulunmaktadır. Üst katmanlarda kirecin yıkanması spesifik özeliklerindendir (Anonim 1991).

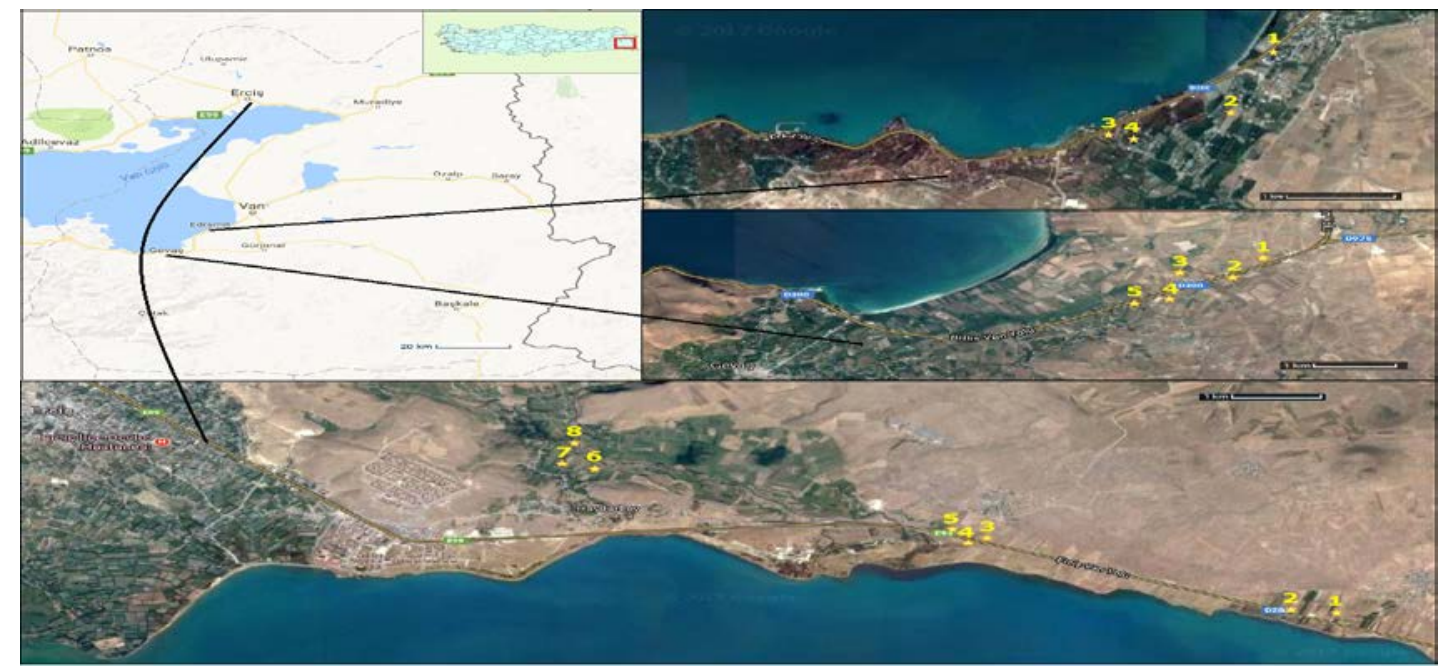

Şekil 1. Araştırmanın yürütüldüğü alanda bitki ve toprak örneklerinin alındığı lokasyonlar.

Edremit ilçesinin iklimi soğuk ve 1lımandır. En fazla yağış kış aylarında düşmektedir. Edremit ilinin yıllık ortalama sıcaklığı $9.3{ }^{\circ} \mathrm{C}$ 'dır. Temmuz $21.5{ }^{\circ} \mathrm{C}$ sıcaklıkla yılın en sıcak ayıdır. Yılın en düşük ortalaması Ocak ayında ortalama sıcaklık -olarak $3.0{ }^{\circ} \mathrm{C}$ 'dir. Yağış miktarı yıllık ortalama 442 mm'dir. Temmuz 4 mm yağışla yılın en kurak ayıdır. En fazla yağış ortalama $64 \mathrm{~mm}$ yağış miktarıyla Nisan ayında görülmektedir (Anonim 2017). Edremit İlçesi toprakları kahverengi büyük toprak grubunda yer almaktadır. $\mathrm{Bu}$ toprak grubunda profil kalsiyum bakımından zengindir. B horizonunun altında kireç birikme zonu vardır (Anonim 1991).

\section{Yöntem}

İlçelerde örnekleme noktalarının sayıları domatesin yetiştirildiği alanların büyüklüğü ile orantılı olacak şekilde belirlenmiştir. Erciş ilçesinde 2050 da alanda, Gevaş ilçesinde 1460 da alanda, Edremit ilçesinde 1112 da alanda domates yetiştiriciliği yapıldığ bildirilmiştir (Anonim 2016). Buna göre, Erciş ilçesinde 8 bahçe, Edremit ilçesinde 4 bahçe, Gevaş ilçesinde 5 bahçe olmak üzere toplam 17 adet örnekleme noktasında, 17 adet toprak örneği ve 4 tekrarlamalı olacak şekilde 68 adet bitkiden yaprak örneği alınmıştır. Şansa bağlı olarak ve domatesin yetiştirildiği alanın büyüklüğü ile orantılı sayıda örnekleme yapılarak alınan yaprak ve toprak örnekleri Yüzüncü Yıl Üniversitesi Ziraat Fakültesi Toprak Bilimi ve Bitki Besleme Bölümüne ait laboratuvara getirilerek, analizleri yapılmıştır.

\section{$\underline{\text { Bitki Örneklerinin Besin Maddesi İceriğinin Belirlenmesi }}$}

Alınan domates bitkisinin yaprak örnekleri laboratuvarda saf sudan geçirilip sabit ağırlı̆̆ına ulaşıncaya kadar $70{ }^{\circ} \mathrm{C}$ kurutulduktan sonra, ögütülüp kimyasal analizlere tabi tutulmuştur. Bitki örneklerinde azot (\%), Kjeldahl yöntemine göre, fosfor (\%), spektrofotometre ile vanado molibdo sarı renk yöntemine göre, makro ve mikro besin elementi (Fe, $\mathrm{Zn}, \mathrm{Cu}, \mathrm{Mn}, \mathrm{Ca}, \mathrm{Mg}, \mathrm{K}$ ) içerikleri kuru yakma sonunda elde edilen ekstraktlarda atomik absorpsiyon spektrofotometre ile belirlenmiştir (Kacar ve İnal 2008).

\section{Toprak Örneklerindeki Fiziksel ve Kimyasal Analizler}

Toprak tekstürü Bouyoucous hidrometre yöntemi ile, toprak reksiyonu 1:2,5 toprak:safsu karışımında pH metre ile, tuz içeriği saturasyon çamurunda elektriksel kondaktivitemetreyle ölçülerek, kireç Scheibler 
kalsimetresiyle, organik madde Modifiye Walkey Black yöntemi ile, azot Kjeldahl yöntemi ile, alınabilir fosfor sodyum bikarbonat yöntemi ile, değişebilir potasyum ise $1 \mathrm{~N}$ amonyum asetat ile atomik absorbsiyon spektrofotometresi ile; sirasi ile Bouyoucous (1951), Jackson (1958), Richards (1954), Ülgen ve Yurtsever (1995), Walkey-Black (1947), Kacar (1994), Olsen ve ark. (1954) ve Thomas (1982) tarafından bildirildiği şekilde yapılmıştır.

\section{Istatistiksel analizler}

Elde edilen bulguların istatistik analizleri ve ortalamaları SAS paket programından yararlanılarak One Way ANOVA yöntemi ile Duncan harflendirilmesi \% 5 olasılık sınır değerine göre yapılmıştır (SAS 1989).

\section{Bulgular ve Tartış ma}

\section{Erciş İlçesindeki Domates Bahçelerine Ait Toprak Özellikleri}

Erciş ilçesinde domates yetiştirilen alanlarda belirlenen toprak özellikleri ve p değerleri Çizelge 1'de verilmiştir.

Çizelge 1. Erciş ilçesi domates bahçelerine ait topraklarının bazı fiziksel ve kimyasal analiz sonuçlanı ile Duncan harflendirmeleri

\begin{tabular}{ccccccccc}
\hline \multirow{2}{*}{ Bahçeler } & \multirow{2}{*}{ Bünye } & Kum & Silt & Kil & $\mathrm{pH}$ & $\mathrm{EC}$ & Kireç & Org. Mad. \\
\cline { 3 - 8 } & & $\%$ & $\%$ & $\%$ & $1: 2.5$ & $\mathrm{dS} / \mathrm{m}$ & $\%$ & $\%$ \\
\hline 1 & Kumlu killi tın & $65.59 \mathrm{f}$ & $2.07 \mathrm{~h}$ & $32.33 \mathrm{a}$ & $8.35 \mathrm{~b}$ & $0.600 \mathrm{f}$ & $11.079 \mathrm{a}$ & $1.7581 \mathrm{c}$ \\
\hline 2 & Kumlu tın & $71.37 \mathrm{~d}$ & $10.53 \mathrm{~d}$ & $18.11 \mathrm{e}$ & $7.89 \mathrm{e}$ & $2.150 \mathrm{~d}$ & $1.132 \mathrm{~b}$ & $2.2124 \mathrm{c}$ \\
\hline 3 & Kumlu tın & $71.79 \mathrm{c}$ & $10.37 \mathrm{e}$ & $17.84 \mathrm{f}$ & $7.30 \mathrm{f}$ & $1.722 \mathrm{e}$ & $1.132 \mathrm{~b}$ & $1.6512 \mathrm{c}$ \\
\hline 4 & Kumlu tın & $77.91 \mathrm{~b}$ & $5.21 \mathrm{~g}$ & $16.88 \mathrm{~g}$ & $7.98 \mathrm{~d}$ & $1.880 \mathrm{e}$ & $0.943 \mathrm{~b}$ & $1.1969 \mathrm{~d}$ \\
\hline 5 & Tinlı kum & $79.87 \mathrm{a}$ & $6.29 \mathrm{f}$ & $13.84 \mathrm{~h}$ & $9.01 \mathrm{a}$ & $2.307 \mathrm{~d}$ & $1.414 \mathrm{~b}$ & $1.2236 \mathrm{~d}$ \\
\hline 6 & Kumlu killi tın & $66.45 \mathrm{e}$ & $12.50 \mathrm{c}$ & $21.04 \mathrm{~d}$ & $8.06 \mathrm{c}$ & $14.680 \mathrm{a}$ & $1.509 \mathrm{~b}$ & $2.5332 \mathrm{~d}$ \\
\hline 7 & Kumlu killi tın & $60.43 \mathrm{~h}$ & $14.89 \mathrm{a}$ & $24.68 \mathrm{~b}$ & $8.30 \mathrm{~b}$ & $6.672 \mathrm{c}$ & $0.943 \mathrm{~b}$ & $2.2793 \mathrm{~b}$ \\
\hline 8 & Kumlu killi tın & $60.63 \mathrm{~g}$ & $12.70 \mathrm{~b}$ & $26.67 \mathrm{c}$ & $8.31 \mathrm{~b}$ & $9.030 \mathrm{~b}$ & $1.320 \mathrm{~b}$ & $2.9608 \mathrm{a}$ \\
\hline $\mathrm{P}$ & - & 0.01 & 0.01 & 0.01 & 0.01 & 0.01 & 0.01 & 0.05 \\
\hline
\end{tabular}

*: Farklı harflerle gösterilen ortalamalar arasındaki fark kendi sütununda önemlidir.

Çizelge 1 incelendiğinde toprakların kum, kil, silt, pH, tuz, kireç içerikleri bakımından bahçeler arasında istatistiksel anlamda \% 1 düzeyinde ve organik madde içerikleri bakımından istatiksel anlamda \% 5 düzeyinde önemli farklılıklar belirlenmiştir.

Erciş ilçesi topraklarının kumlu killi tın, kumlu tın, tınlı kum tekstür sınıflarında olduğu belirlenmiştir. Toprakların pH değerleri literatürde Kellog (1952), bildirilen sınır değerler ile kıyaslandığında (7.5 ve 7.8) göre genellikle hafif alkali reaksiyonlu, organik madde (\% 1.19-2.96) ve tuzsuz (0.60-14.68 dS/m) bulunmuştur. Çizelge 1'de toprakların kireç içerikleri 4 nolu bahçe dişında az düzeyde (\% $1-\%$ 5) bulunmuştur.

Erciş ilçesinde domates yetiştirilen alanlarda toprakların organik madde içeriği bakımından yetersiz olması Gülser (1992), tarafından aynı alanda yapılan araştırma sonuçları ile uyum sağlamaktadır.

\section{Gevaş Illçesinde Domates Bahçelerinin Toprak Özellikleri}

Gevaş ilçesinde domates yetiştirilen alanlarda belirlenen toprak özellikleri ve p değerleri Çizelge 2'de verilmiştir.

Çizelge 2 incelendiğinde toprakların kum, kil, silt ve kireç değerleri bakımından istatistiksel anlamda \% 1 düzeyinde önemli farklılıklar elde edilmiş ve $\mathrm{pH}$ ve organik madde içerikleri ile EC değerleri bakımından istatistiksel anlamda \% 5 düzeyinde önemli farklılıklar belirlenmiştir. 
Çizelge 2. Gevaş ilçesi domates bahçelerinde toprakların bazı fiziksel ve kimyasal özellikleri ile Duncan harflendirmeleri

\begin{tabular}{ccccccccc}
\hline \multirow{2}{*}{ Bahçeler } & \multirow{2}{*}{ Bünye } & Kum & Silt & Kil & $\mathrm{pH}$ & $\mathrm{EC}$ & Kireç & Org. Mad. \\
\cline { 2 - 8 } & & $\%$ & $\%$ & $\%$ & $1: 2.5$ & $\mathrm{dS} / \mathrm{m}$ & $\%$ & $\%$ \\
\hline 1 & Kumlu killi tın & $48.48 \mathrm{a}$ & $23.04 \mathrm{~b}$ & $28.48 \mathrm{e}$ & $9.40 \mathrm{a}$ & $4.713 \mathrm{~b}$ & $14.804 \mathrm{c}$ & $2.1323 \mathrm{dc}$ \\
\hline 2 & Kil & $37.68 \mathrm{~d}$ & $18.95 \mathrm{e}$ & $43.37 \mathrm{~b}$ & $8.95 \mathrm{ba}$ & $19.940 \mathrm{a}$ & $8.200 \mathrm{~b}$ & $2.8004 \mathrm{ba}$ \\
\hline 3 & Kumlu killi tın & $46.10 \mathrm{~b}$ & $20.00 \mathrm{~d}$ & $33.90 \mathrm{~d}$ & $8.70 \mathrm{~b}$ & $18.400 \mathrm{a}$ & $11.268 \mathrm{~d}$ & $1.8784 \mathrm{~d}$ \\
\hline 4 & Killi tın & $38.73 \mathrm{c}$ & $26.32 \mathrm{a}$ & $34.95 \mathrm{c}$ & $8.83 \mathrm{~b}$ & $18.780 \mathrm{a}$ & $6.600 \mathrm{e}$ & $2.4263 \mathrm{bc}$ \\
\hline 5 & Kil & $38.73 \mathrm{c}$ & $21.88 \mathrm{c}$ & $45.00 \mathrm{a}$ & $9.09 \mathrm{ba}$ & $8.200 \mathrm{~b}$ & $28.288 \mathrm{a}$ & $3.1746 \mathrm{a}$ \\
\hline $\mathrm{P}$ & - & 0.01 & 0.01 & 0.01 & 0.05 & 0.05 & 0.01 & 0.05 \\
\hline
\end{tabular}

*: Farklı harflerle gösterilen ortalamalar arasındaki fark kendi sütununda önemlidir.

Gevaş ilçesindeki domates bahçe topraklarının kumlu killi tın, kil, killi tın bünyeli olduğu belirlenmiştir. Toprakların kuvvetli alkali (pH: 8.5) reaksiyonlu, genellikle fazla tuzlu $(<0.65 \mathrm{dS} / \mathrm{m})$, orta ve yüksek düzeyde kireçli, organik madde (\% 1-2) bakımından yetersiz sınırında yer aldığı belirlenmiştir (Çizelge 2).

Gevaş ilçesinde domates yetiştirilen topraklarda organik madde içeriği bakımından yetersiz olması Gülser (1992), aynı alanda yaptığı araştırma sonucu ile uyum sağlamaktadır.

\section{Edremit İlçesinde Domates Bahçelerinin Toprak Özellikleri}

Edremit ilçesinde domates yetiştirilen alanlarda belirlenen toprak özellikleri ve p değerleri Çizelge 3' de verilmiştir.

Çizelge 3. Edremit ilçesi domates bahçelerinde toprakların bazı fiziksel ve kimyasal özellikleri ile Duncan harflendirmeleri

\begin{tabular}{ccccccccc}
\hline \multirow{2}{*}{ Bahçeler } & \multirow{2}{*}{ Bünye } & Kum & Silt & Kil & $\mathrm{pH}$ & $\mathrm{EC}$ & Kireç & Org. Mad. \\
\cline { 2 - 8 } & & $\%$ & $\%$ & $\%$ & $1: 2.5$ & $\mathrm{dS} / \mathrm{m}$ & $\%$ & $\%$ \\
\hline 1 & Killi tın & 33.47a & $34.20 \mathrm{~d}$ & 32.33a & $9.20 \mathrm{a}$ & $2.635 \mathrm{~d}$ & $3.206 \mathrm{c}$ & $2.3461 \mathrm{ba}$ \\
\hline 2 & Kill & 29.32c & $42.70 \mathrm{c}$ & $27.98 \mathrm{~b}$ & $9.03 \mathrm{ba}$ & $9.400 \mathrm{a}$ & $27.156 \mathrm{~b}$ & $1.9986 \mathrm{~b}$ \\
\hline 3 & Kill & 32.42b & $43.37 \mathrm{~b}$ & $24.21 \mathrm{c}$ & $8.89 \mathrm{~b}$ & 8.892b & $27.439 \mathrm{ba}$ & $3.1211 \mathrm{a}$ \\
\hline 4 & Kill & $33.47 \mathrm{a}$ & $21.76 \mathrm{~d}$ & $44.77 \mathrm{a}$ & $8.24 \mathrm{c}$ & 8.240c & $29.042 \mathrm{~d}$ & $2.1055 \mathrm{~b}$ \\
\hline $\mathrm{P}$ & - & 0.01 & 0.01 & 0.01 & 0.05 & 0.01 & 0.01 & 0.05 \\
\hline
\end{tabular}

*: Farklı harflerle gösterilen ortalamalar arasındaki fark kendi sütununda önemlidir.

Çizelge 3 incelendiğinde farklı bahçe toprakları arasında kum, kil, silt, tuz, kireç bakımından istatistiksel anlamda \% 1 düzeyinde önemli farklılıklar belirlenmiştir. Toprakların $\mathrm{pH}$ değerleri ve organik madde bakımından ise bahçeler arasında istatistiksel anlamda \% 5 düzeyinde önemli farklılıklar elde edilmiştir.

Edremit ilçesindeki domates bahçe topraklarının killi tın ve kil bünyeli olduğu belirlenmiştir. Toprakların kuvvetli alkali ( $\mathrm{pH}$ 8.5) reaksiyonlu, genellikle tuzlu, 1 nolu bahçede az kireçli, diğerlerinde orta düzeyde kireçli, organik madde (\% 1-2) bakımından yetersiz özellikler taşıdı̆̆ belirlenmiştir (Çizelge 3).

Edremit ilçesinde domates yetiştirilen alanlarda organik madde içerikleri yetersiz düzeyde bulunmuştur. Gülser (1992), tarafinda bu alanda yapılan çalışmada topraklarda benzer sonuçlar elde edilmiştir.

İçelere göre toprakların makro ve mikro besin elementi içerikleri

Çalışma yapılan ilçelerde domates yetiştirilen alanlarda belirlenen toprak besin elementi içerikleri Şekil 2 ve 3 'de verilmiştir. 


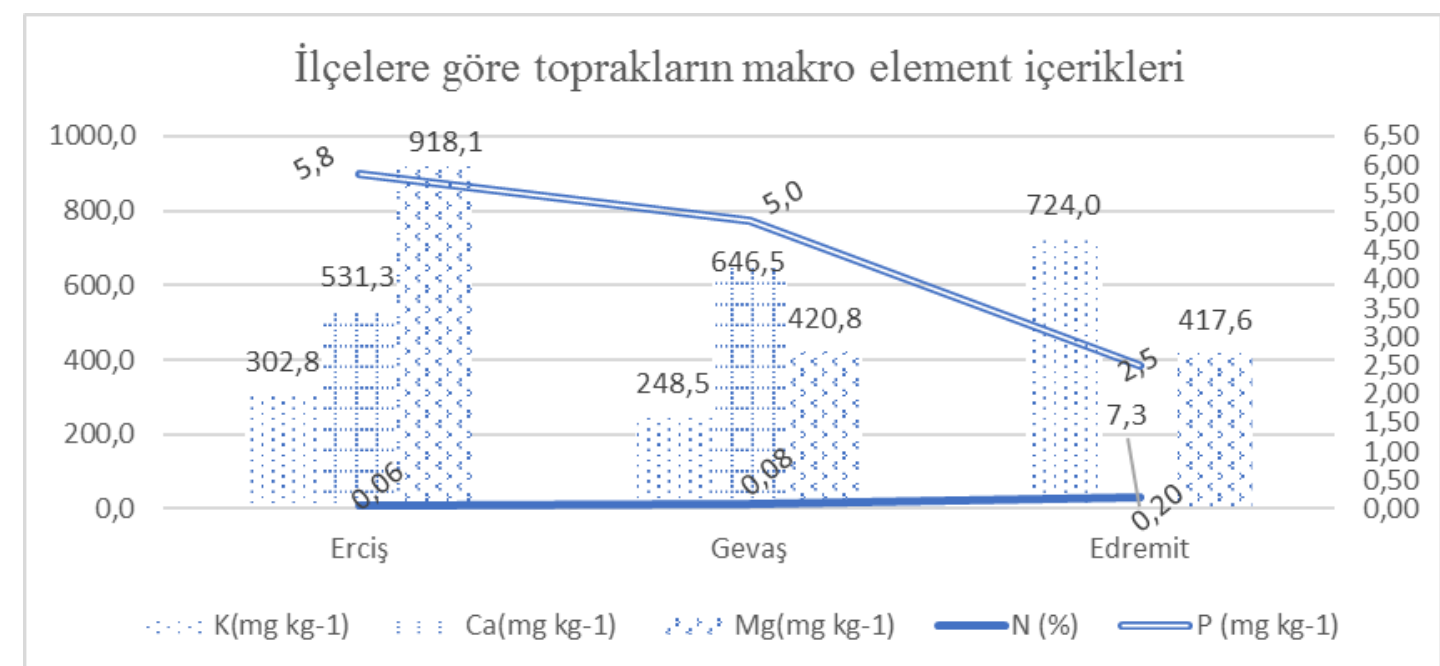

Şekil 2. Erciş, Gevaş ve Edremit ilçelerinde domates yetiştirilen alanlarda belirlenen toprak makro besin elementi içerikleri.

Erciş ilçesinde toprakların azot, demir, mangan, çinko ve bakır besin elementi içerikleri bakımından bahçeler arasında istatistiksel anlamda \% 5 düzeyinde önemli farklılıklar elde edilmiş ve fosfor, kalsiyum ve magnezyum besin elementi içerikleri bakımından bahçeler arasında \% 1 düzeyinde önemli farklılıklar belirlenmiştir. Edremit ilçesi domates bahçelerine ait $\mathrm{Mg}$ içerikleri bakımından istatistiksel anlamda \% 1 düzeyinde önemli farklılıklar belirlenmiştir. İlçelerdeki domates bahçe topraklarının azot (\% 0.045$0.090)$, yarayışlı fosfor $(2.5-8.0 \mathrm{mg} / \mathrm{kg}$ ) bakımından yetersiz sınırında ve potasyum (140-370 mg/kg), kalsiyum (1 150-3 $500 \mathrm{mg} / \mathrm{kg})$, magnezyum (160-1 $000 \mathrm{mg} / \mathrm{kg}$ ) içeriklerinin yeterli olduğu belirlenmiştir (Şekil 2).

İlçelerde domates yetiştirilen alanlarda toprakların azot ve yarayışlı fosfor içerikleri bakımından yetersiz olması Gülser (1992), tarafından aynı alanda yapılan araştırma sonuçları ile uyum sağlamaktadır.

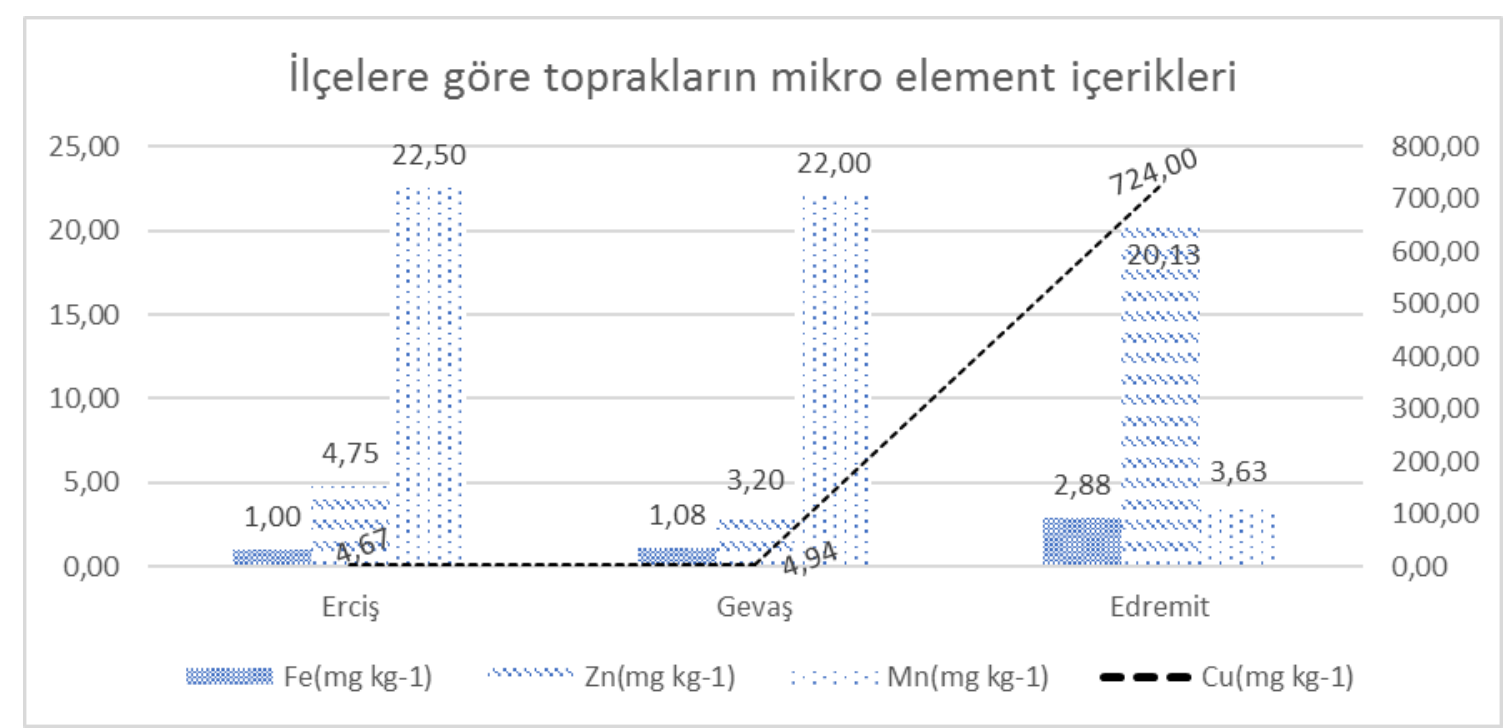

Şekil 3. Erciş, Gevaş ve Edremit ilçelerinde domates yetiştirilen alanlarda belirlenen toprak mikro besin elementi içerikleri.

İlçelerin domates bahçe topraklarının, Gevaş ilçesinde domates yetiştirilen 1 nolu lokasyon topraklarının demir içeriği dışında Lindsay ve Norwel (1969) tarafından bildirilen sınır değerlere göre Fe (0.2-4.5 $\mathrm{mg} / \mathrm{kg}$ ) yeterli, $\mathrm{Zn}(0.7-2.4 \mathrm{mg} / \mathrm{kg}), \mathrm{Mn}(170-856 \mathrm{mg} / \mathrm{kg}), \mathrm{Cu}(0.2 \mathrm{mg} / \mathrm{kg})$ içerikleri yeterli ve yüksek düzeyde bulunmuştur (Şekil 3). 
Erciş ilçesinde domates yetiştirilen alanlarda toprakların Fe içeriğinin orta düzeyde olması Gülser (1992) tarafından aynı alanda yapılan araştırma sonuçları ile uyum sağlamaktadır.

\section{Erciş, Gevaş ve Edremit ilçelerinde domates bitkisinin besin elementi içeriği}

Erciş ilçesinde, varyans analiz sonuçlarına göre bahçeler arasında bitkinin besin elementi içeriği azot, fosfor ve mangan değerleri bakımından istatistiksel anlamda \% 1 düzeyinde ve çinko içeriği bakımından istatistiksel anlamda \% 5 düzeyinde önemli farklılıklar belirlenmiştir.

Varyans analiz sonuçlarına göre, Gevaş ilçesinde bahçeler arasında bitkinin besin elementi içeriği bakımında istatistiksel anlamda azot ve kalsiyum bakımından \% 1 düzeyinde önemli farklılıklar belirlenmiştir.

Edremit ilçesinde, varyans analiz sonuçlarına göre fosfor içeriği bakımından bahçeler arasında istatistiksel anlamda \% 1 düzeyde ve çinko içeriği bakımından bahçeler arasında istatistiksel anlamda \% 5 düzeyde önemli farklılıklar belirlenmiştir.

Çalışma yapılan ilçelerde domates bitkisinin makro ve mikro besin elementi içerikleri Şekil 4 ve 5'te verilmiştir.

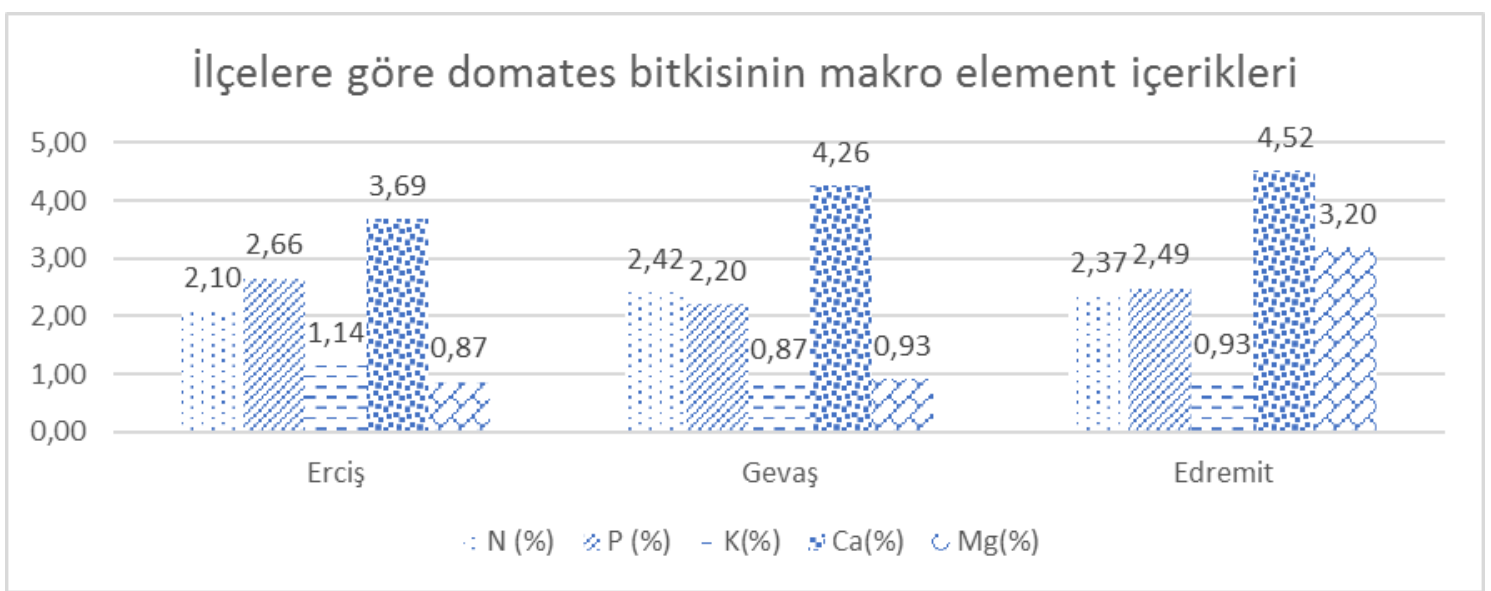

Şekil 4. Erciş, Gevaş ve Edremit ilçelerinde domates bitkisinin makro besin elementi içerikleri.

Jonnes ve ark. (1991), tarafindan bildirilen sınır değerlerine göre, Erciş ilçesindeki domates bitkisi yapraklarından azot $(\% 3.5)$ ve potasyum (\% 2.5) dışında herhangi bir besin elementi noksanlığ 1 belirlenmemiştir. Azot içerikleri \% 1.638-2.527 arasında değişim göstermiştir. Potasyum içerikleri ise \% 1.03-1.197 arasında belirlenmiştir. Fosfor (\% 0.3 ), kalsiyum (\% 0.3), magnezyum (\% 0.15 ) içerikleri ise Jonnes ve ark. (1991) tarafından bildirilen sınır değerlerine göre yeterli düzeyde bulunmuştur (Şekil 4).

Erciş ilçesi domates bahçeleri topraklarında yarayışlı fosfor içeriğinin yetersiz düzeyde belirlenmiş olmasına rağmen, bitkide yüksek bulunmasının tarımsal mücadele ilaçlarından kaynaklanmış olabileceğ düşünülmektedir. Ayrıca Erciş ilçesi topraklarının dahil olduğu kireçsiz Kahverengi büyük toprak grubunda, bildirilen (TOVEP 1991) kalsiyum yıkanması nedeniyle bitkilerde kalsiyum noksanlığının gerçekleştiği kanaatine varılmıştır.

Jonnes ve ark. (1991), tarafinda bildirilen sınır değerlerine göre Gevaş ve Edremit ilçelerindeki domates yapraklarında azot dışında herhangi bir makro besin elementi noksanlığ 1 belirlenmemiştir. Gevaş ve Edremit ilçelerinde azot içerikleri sırası ile \% 2.072-2.76 ve \% 2.170- \% 2.765 arasında değişim göstermiştir. Ayrıca fosfor (> \% 0.3), potasyum (> \% 5), kalsiyum (> \% 3), magnezyum (> \% 0.15) içerikleri ise Jonnes ve ark. (1991) tarafından bildirilen sınır değerlerine göre yeterli düzeyde bulunmuştur (Şekil 4). 


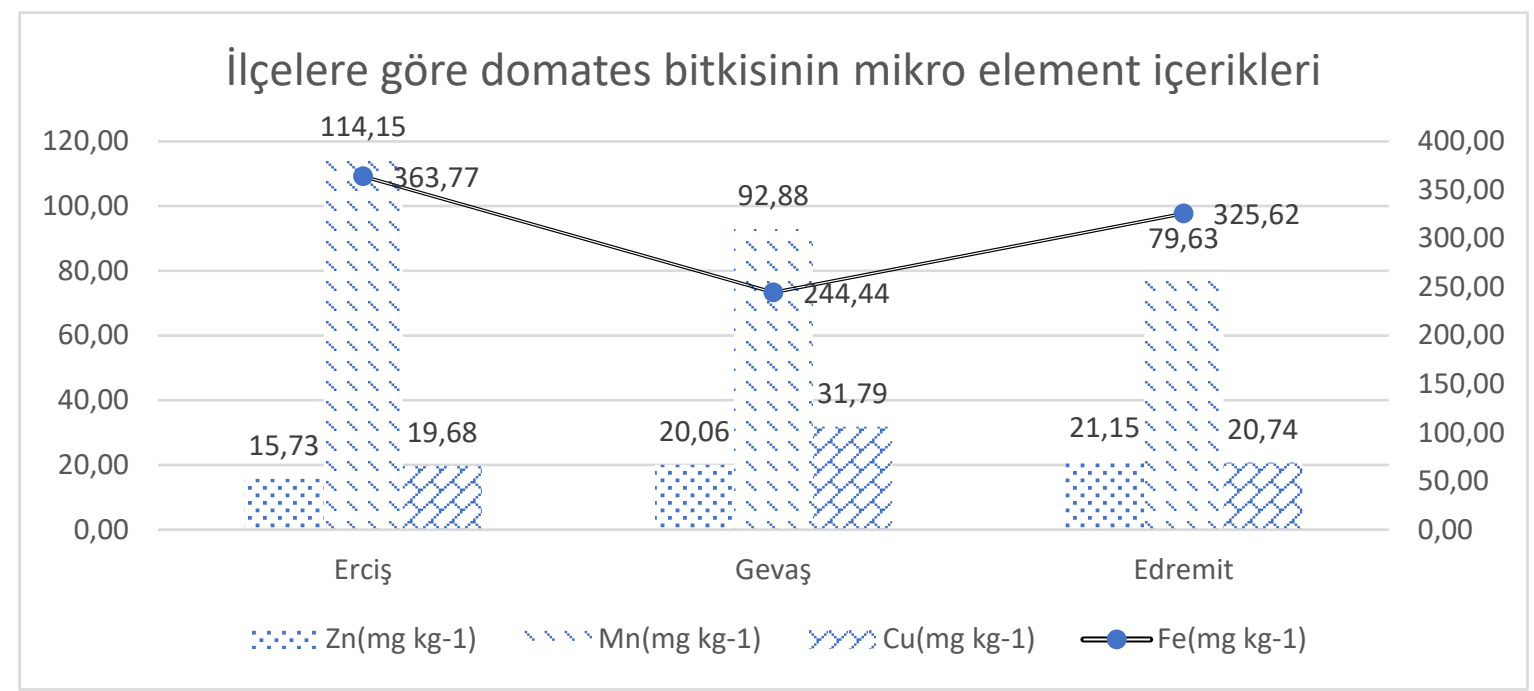

Şekil 5. Erciş, Gevaş ve Edremit ilçelerinde domates bitkisinin mikro besin elementi içerikleri.

Jonnes ve ark. (1991), tarafindan bildirilen sınır değerlerine göre, Erciş, Gevaş ve Edremit ilçelerindeki domates bitkisi yapraklarında demir $(50 \mathrm{mg} / \mathrm{kg})$, çinko $(20 \mathrm{mg} / \mathrm{kg})$, mangan $(20 \mathrm{mg} / \mathrm{kg})$ ve bakır (5 $\mathrm{mg} / \mathrm{kg}$ ) içerikleri yeterli düzeyde bulunmuştur(Şekil 5).

Araştırmanın yürütüldüğü 3 lokasyonda da topraklarda organik madde, azot, yarayışlı fosforun yetersiz olduğu belirlenmiştir. Toprakların kalsiyum içeriği Erciş ilçesi dışında genellikle yeterli bulunmuştur. Mikro besin elementleri bakımından demir dışında herhangi bir besin elementi noksanlığı bulunmamıştır. Lokasyonlar arasında toprak özellikleri bakımında elde edilen farklılıkların farklı lokasyonlardaki toprakların farklı büyük toprak gruplarına dahil olmasından (Anonim 1971) kaynaklandığ1 düşünülmektedir.

Aydeniz (1985), Türkiye topraklarının organik madde, azot ve yarayışlı fosfor bakımında yetersiz olduğunu bildirmiştir. Uzun yıllardır yerleşim alanı olmasından kaynaklı toprak yorgunluğu, ormanların ve doğal vejetasyonun tahrip edilmesi, eğimli topografyadan dolayı meydana gelen toprak kayıpları, erozyon ve sıcak kurak iklimin bunda etkili faktörler olduğunu belirtmiştir.

Demir eksikliği dünya topraklarında ve Türkiye topraklarında yaygın olarak ortaya çıkmaktadır (Erdal ve ark. 2013). Kireçli toprak ana materyali ve yüksek pH düzeyi, killi bünye demir eksikliğinde etkili faktörlerdir. Bu çalışmada demir içeriğinde elde edilen sonuçlar daha önce yapılan çalışmaların sonuçları ile uyum sağlamaktadır. Gülser (1992), Van Gölü havzası topraklarında çinko içeriğinin kritik düzeyde olduğunu bildirmiştir. $\mathrm{Bu}$ çalışmada araştırma alanı topraklarında belirlenen yüksek çinko değerlerinin domates bahçelerine uygulandığ kaynaklandığ1 düşünülmektedir.

Benzer şekilde Gevaş ve Edremit topraklarında belirlenmiş olan yüksek tuz düzeylerinin uygulanan gübre ve tarımsal mücadele ilaçlarından kaynaklandığ 1 düşünülmektedir.Bu çalışmada araştırmanın yürütüldügü 3 lokasyonda da domates bitkisinde yaprakların azot içeriğinin yetersiz olduğu belirlenmiştir. Ayrıca Erciş ilçesinde domates bitkisinin yapraklarında potasyumiçeriği yetersiz düzeyde bulunmuştur.

$\mathrm{Bu}$ çalışmada Van ilinde domates bitkisinin beslenme durumu ortaya konulmuştur. Noksanlığı belirlenen besin elementleri dikkate alınarak yapılacak gübre uygulamaları ile ileriki dönemlerde veriminin artırılması mümkün görülmektedir.

Tarımsal üretimde verim artışında gübrelemenin çok büyük önem taşıdığ1 bilinmektedir. Ancak bilinçli gübreleme yapıldığı takdirde verim artışı ve kaliteli ürün elde etme açısından optimum sonuçların elde edilebileceği bir gerçektir. Bilinçli gübreleme ise herhangi bir ürünün yetiştirildiği alanın fiziksel ve kimyasal toprak özelliklerinin belirlenmesi, besin elementi içeriklerinin analiz edilmesi ve bunun yanında 
söz konusu ürünün topraktaki besin elementlerinden ne ölçüde yararlanabildiğinin yani bitkinin beslenme durumunun ortaya konulması sonucu tavsiye edilebilecek gübreleme programı ile mümkündür.

Böyle bir gübreleme programı hem bitkinin ihtiyacı olan besin elementlerinin eksiksiz olarak karşılanabilmesini sağlayacak hem de olası gereksiz ya da aşırı gübre tüketimini engelleyecektir. Ayrıca aşırı gübrelemeden kaynaklanabilecek toprak kalitesindeki bozulmaların, besin elementi dengesizliklerinin ve ekonomik kayıpların önüne geçilebilecektir.

Azot noksanlığı bitkilerde vejetatif gelişmeyi geriletmekte ve generatif faaliyeti hızlandırarak ürün miktarında önemli düzeyde azaltmaya neden olmaktadır. Azot noksanlı̆̆ının derecesine bağlı olarak bitkilerde az ya da çok bodur büyüme ve sürgün oluşumunda gerileme ve özellikle yapraklarda büyümenin azaldığ 1 bildirilmiştir (Kacar ve Katkat 2005). Bu bakımından araştırma alanında belirlenen topraklarda organik madde, azot noksanlı̆̆ının giderilmesinin verim artışında etkili olabileceği düşünülmüştür.

Domatesin kumludan killiye kadar derin geçirgen ve su tutma kabiliyeti iyi humus ve besin maddelerince zengin tınlı topraklarda iyi ürün verdiği belirtilmiştir (Anonim 2011). Bu bakımından araştırma alanında belirlenen topraklarda organik madde ve azot noksanlığının giderilmesinin verim artışında etkili olabileceği düşünülmüştür. Altuntaş (2016) $15 \mathrm{mg} / \mathrm{l}$ prohexadione kalsiyum uygulaması ile domates bitkisinde verim artış1 elde edildiğini bildirmiştir.

Azot noksanlığ belirlenen alanlarda bilinçli azotlu gübre uygulamalarının verime ve kaliteyi önemli düzeyde artırdığı bilinmektedir (Kacar ve Katkat 2014). Bu araştırmanın yürütüldüğü alanlarda toprak organik maddesi ve azotun yetersiz oluşu dolayısı ile topraklara çiftlik gübresi, yeşil gübre ya da kompost gibi organik madde ilavelerinin yanında kimyasal gübre uygulamalarının yararlı olabileceği sonucuna varılmıştır. Ayrıca Erciş ilçesinde bitkilerde belirlenen potasyum eksikliğinin giderilmesi için potasyumlu gübrelerin uygulanması uygun bulunuştur.

\section{Sonuç}

Araştırma alanları topraklarında belirlenmiş olan organik madde ve azotun düşük düzeylerinin domates bitkisinde azot noksanlığına neden olduğu ortaya çıkmıştır. Bundan kaynaklana bilecek bitki gelişimindeki gerileme ve verimdeki azalmanın önüne geçebilmek için topraklara organik madde ve azot ilavesinin yararlı olacağı öngörülmektedir. Ayrıca Edremit ilçesinde bitkilerde belirlenen potasyum eksikliğinin giderilmesi için potasyumlu gübrelerin uygulanması uygun bulunuştur.

Araştırma alanları toprakları alkali karakterli olduğunda amonyum sülfat gibi asit karakterli gübrelerin uygulanması öngörülmektedir (Kacar ve Katkat 2014). Ayrıca Edremit ilçesinde bitkilerde belirlenen potasyumnoksanlığından dolayı potasyumlu gübrelemeye ağırlık verilmesi gerekliliği ortaya çıkmıştır.

\section{Teşekkürler}

Bu çalışma Sezgin BAYRAM'ın yüksek lisans tezinden türetilmiştir.

\section{Kaynaklar}

Altuntaş Ö (2016). Prohexadione-Ca uygulamalarının domateste bitki büyümesi besin element alımı ve meyve kalitesi üzerine etkileri. YYÜ TAR BİL DERG, 26(1): 98-105.

Anonim (1971). Vangölü Havzası Toprakları. Toprak Su Genel Müdürlüğü Yayınları no: 261.

Anonim (1991). Türkiye Toprakları Verimlilik Envanteri. T.C. Tarım Orman ve Köyişleri Bakanlığı Köy Hizmetleri Genel Müd.

Anonim (2008). Domates Yetiştiriciliği http://1hbogm. meb. gov. tr/ moduler programlar/ kurs programlari/.../domates_yetistiriciligi (Erişim tarihi: 22.05.2015).

Anonim (2011). Domates HYPERLINK "http://www.bitkiselyag.org/domates-solanum-lycopersicum/" (Solanum lycopersicum HYPERLINK "http:// www.bitkiselyag.org/ domates-solanumlycopersicum/") HYPERLINK "http:// www. bitkiselyag.org/ domates-solanum-lycopersicum/" http://www.organikoop.com/domates-(solanum-lycopersicum)

HYPERLINK "http://www.bitkiselyag.org/domates-solanum-lycopersicum/" (15.08.2015). 
Anonim (2016). Seçilmiş göstergelerle Van. www.tuik.gov.tr/ il Gostergeleri/ iller/ VAN.pdf (Erişim tarihi: 15.03.2017).

Anonim (2016). Domates üretiminin yarısı beş ilde. https:// www.haberturk.com/ ekonomi/isyasam/haber/1509942-domates-uretiminin-yarisi-bes-ilde.( Erişim tarihi 22.06.2018).

Anonim (2017). İklim Van İklim grafiği, Sıcaklık grafiği, İklim tablosu Climate Data.org https://r.climate-data.org/locationHYPERLINK "https:// tr.climate-data.org/ location/21486"/21486 (Erişim tarihi: 03.06.2017).

Aydeniz A (1985). Toprak Amenajmanı. Ankara Üniversitesi Ziraat Fakültesi Yayınları: 928. Ders Kitabi: 263.

Bouyoucous GD (1951). A. recablibration of the hydrometer method for making mechanical analysis of the soil. Agronomy J., 43: 434-438.

Erdal İ, Kaplankıran B, Evren E, Küçükyumuk Z, Türkan AŞ (2013). Farklı demir içeriklerine sahip besin çözeltisiyle beslenen domates bitkisinin gelişimi, toplam demir, aktif demir klorofil ve spad değerleri arasındaki ilişkiler. Yüzüncü Yıl Üniversitesi, Ziraat Fakültesi Tarım Bilimleri Dergisi, 24(1):36-41.

Gülser F (1992). Van gölü havzası büyük toprak gruplarının verimlilik durumları. Yüzüncü Yıl Üniversitesi Fen Bilimleri Enstitüsü. Yüksek Lisans Tezi.

Jackson, M (1958). Soil Chemical Analysis. Prentice Hall, Inc. New Jersey, USA.

Jonnes Jr. JB, Wolf B, Mills HA (1991). Plant Analysis Handbook. Micro macro Publishing Inc.

Kacar B (1994). Bitki ve Toprağın Kimyasal Analizleri: III Toprak Analizleri. Ankara Üniversitesi Ziraat Fakültesi Eğitim Araştırma ve Geliştirme Vakfı Yayınları No: 3, Ankara, 705s.

Kacar B, Katkat AV (2005). Bitki Besleme. Uludağ Üniversitesi Güçlendirme Vakfi Yayın no: 127 VİPAȘ Yayınları: 32005.

Kacar B, Katkat AV (2014). Gübreler ve Gübreleme Tekniği ISBN: 978-605-5426-20-0. Ankara.

Kacar B, İnal A (2014). Bitki Analizleri Nobel Yayın: 1241, Fen bilimleri: 6.

Kellog CE (1952). Our Garden Soils. The Macmillan Company. New York. p. 232.

Keskin G (2012). Domates ve domates salçası durum - Tahmin Tarımsal Ekonomi Ve Politika Geliştirme Enstitüsü Tepge Yayın. NO: 219 S 1-3.

Lindsay WL, Norwell WA (1969). Development of a DTPA Micronutrient Soil Test. Pages 600-602, in Soil Sci. Am. Proc. 35.

Richards DC (1954). Salinity Loboratory Staff. Contributing Authors: U. S. Salinity Loboratory L.A. Rev.ed.

Richards LA (1954). Diagnosis and Improvement of Saline and Alkali Soils. United Satates Department of Agriculture Handbook. 60: 90. Wastington, D C. United states Goverment Printing Office.

Sarısaçlı İE (2010). Domates salçası. T.C. Başbakanlık Dış Ticaret Müsteşarlığı İhracatı Geliştirme Etüd Merkezi raporu. http://www.cedam.com/Fileupload/bs238314/file/ (Erişim tarihi: 08.05.2017).

SAS Institute (1989). SAS User’s Guide. Statics. Version 6,4+4 ed Vol.2. Sas Institute, Cary. Nc.

Thomas GW (1982). Exchangeable cations. Chemical and Microbiological properties Agronomy Monograph. No: 7. P 159-165. (2nd Ed.) ASASSSA, Madison, Wisconsin, USA.

Tovep 1991. Türkiye Toprakları Verimlilik Envanteri. T.C.Tarım Orman ve Köyişleri Bakanlığı Köy Hizmetleri Gen. Müd. Ankara.

Ülgen N, Yurtsever N (1995). Türkiye gübre ve gübreleme rehberi. Toprak ve Gübre Araştırma Enstitüsü Yayınları, Genel yayın No: 209, Teknik Yayınlar No: T.66, Ankara.

Walkey A (1947). A critical examination of a rapid method for determining organiccarbon in soils: effect of varations in digestion conditionsand inorganic soil constiuents. Soil Science, 63: 251-263. 